\title{
An Annotated Checklist to the Chenopod Flora of Sudan
}

\author{
Gamal E. B. El Ghazali ${ }^{1}$
}

${ }^{1}$ Medicinal and Aromatic Plants Research Institute, National Centre for Research, P.O. Box 2404, Khartoum, Sudan

\begin{abstract}
The aims of the present study are to provide biodiversity assessment and to contribute to the updating the flora of Sudan. A total of (28) species belonging to (15) genera were compiled to comprise members of the family Chenopodiaceae in the Sudan, with the addition of (12) new records. Range extension of (6) species and habitatspecific trends of (10) species were recorded. These species were compiled as a result of comprehensive literature review, herbarium collections and long-term field surveys. Anabasis ehrenbergii, Kochia cana, Sevada schimperi were previously recorded in the main Flora but were no longer reported by subsequent floristic studies (specially along the Red Sea Coastal region), and may be regarded as extinct or vanished. The disappearance of these species was attributed to destruction of natural habitats and climatic changes, suggesting the need for conservation efforts.
\end{abstract}

Keywords: New Records, Range Extension, Habitat-Specific, Extinction, Kochia cana

\section{Introduction}

Sudan is one of the African countries whose flora and vegetation are scarcely studied and the available data are limited to few regions and families or are relatively old, and in need for an update or revision.

The Chenopods of the Sudan were last documented by Andrews (1950). Since then, numerous changes have occurred in the flora and no attempt was made for updating. Many floristic studies reporting new records, have already been published or are included in academic theses, dissertations or reports, covering different regions of Sudan, should be added to the flora. They are dispersed in local, regional and international sources and are often difficult to access and less frequently compiled. Moreover, many plants have changed names in view of recent taxonomic studies and many plants have been introduced and became naturalized.

Chenopodiaceae (Goosefoot family) is a vascular plant family with probably 110 genera and 1700 species and inhabiting mainly arid to semi arid, deserts, disturbed, agricultural, coastal and saline habitats (Zhu et al. 2003, Kadereit et al. 2003). Members of this family are mostly herbs or shrubs, rarely dwarf trees, mostly xerophytic or halophytic (Freitag et al. (2001). The family was previously placed in Caryophyllales, Chenopodiales, Centrspermae and Curvembryeae by Cronquist (1981), Thorne (1992), Ulbrich (1934) and Bentham \& Hooker (1880) respectively. Recently, Angiosperm Phylogeny Group (APG 1998, 2003, 2009, 2016) have included the family Chenopodiaceae in the family Amaranthaceae on molecular bases, whereas
Hernandez-Ledesma et al. (2015) regarded it as a distinct family and separated from the Amaranthaceae.

According to Andrews (1950), the family Chenopodiaceae is represented by 16 species belonging to 9 genera. This number of species appear to be low considering the country size, presence of several climatic and vegetation belts (FAO 2005).

The aim of the present study is to bring together more recent information on members of the family Chenopodiaceae documented in diverse sources and herbaria in an attempt to provide the basis for further studies on indigenous species, biodiversity assessments, and to facilitate subsequent taxonomic works contributing to update the flora of Sudan.

\section{Material and Methods}

The present study has been compiled based on literature sources, herbarium collections deposited at (KHU), and long-term field surveys. The literature surveys was conducted on various sources documenting the presence and distribution of members of the family Chenopodiaceae in Sudan. Updated nomenclature of the species compiled has been verified using "The Plant List" published at (http://www.theplantlist.org/, version 1:1 (2003), and according to Akhani et al. (2007), Mosyakin \& Clemants (2008), Fuentez-Bazen et al. (2012), Hernandez-Ledesma et al. (2015) and Piirainen et al. (2017).

As far as possible, scientific name of each plant is given together with the author of the binomial, 
synonyms only when the plant name has changed since the publication of the Flora and geographical distribution at the regional level together with citation of source.

All the species (native or naturalized) compiled for the family Chenopodiaceae in the Sudan both recently occurring and previously reported (extinct or vanished), were included and arranged alphabetically, and new species records are marked with an asterisk.

\section{Results}

The present study resulted in an updated checklist of members of the Chenopodiaceae known to occur in Sudan, which include (28) species belonging to (15) genera, with an increase of (12) species regarded as new records for Sudan. All the species compiled to comprise members of the Chenopodiaceae in Sudan are documented below.

\begin{tabular}{|c|c|}
\hline$* 1$ & Anabasis setifera Moq. Red Sea Coasts (Alawad 1994). \\
\hline$* 2$ & Anabasis ehrenbergii Schweinf. ex Boiss. Red Sea Coasts (Kassas 1957). \\
\hline 3 & $\begin{array}{l}\text { Arthrocaulon macrostachyum (Moric.) Piirainen \& Kadereit (= Arthrocnemum glaucum (Del.) } \\
\text { Ung.- Sternb.). Red Sea Coasts (Broun \& Massey 1929, Andrews 1950, Kassas 1957, Hassan } \\
\text { 1974, Alawad 1994, Sugga 1999, Woldewahid et al. 2007). }\end{array}$ \\
\hline 4 & $\begin{array}{l}\text { Atriplex farinosa Forssk. Red Sea Coasts (Broun \& Massey 1929, Andrews 1950, Kassas 1957, } \\
\text { Hassan 1974, Boulos et al. 1991, Alawad 1994, Karrar 2010), Kassala (Ahti et al. 1973). }\end{array}$ \\
\hline$* 5$ & $\begin{array}{l}\text { Atriplex halimus L. Sudan (https://pfaf.org/plants). Note that this species is not included in other } \\
\text { internet sources e.g. GBI, Catalogue of Life and Encyclopedia of Life. }\end{array}$ \\
\hline$* 6$ & Bassia eriophora (Schrad.) Asch. (=Kochia eriophora Schrad.). Red Sea Coasts (Alawad 1994). \\
\hline$* 7$ & Bassia indica (Wight) A.J. Scott. (= Kochia indica Wight). Sudan (Brummitt 2001). \\
\hline$* 8$ & $\begin{array}{l}\text { Caroxylon cyclophyllum (Baker) Akhani \& Roalson (= Salsola cyclophylla Baker). Sudan } \\
\text { (Boulos 1999). }\end{array}$ \\
\hline 9 & $\begin{array}{l}\text { Caroxylon imbricatum (Forssk.) Akhani \& Roalson (= Salsola imbricata Forssk. , S. baryosma } \\
\text { (schult.) Dandy., S. foetida Del. \& Moq.). Northern Sudan (Andrews 1950), Wadi Halfa (Broun } \\
\text { \& Massey 1929, Pettet et al. 1964, Ahti et al. 1973, El Hadidi 1976, Ali 2006), Red Sea Coasts } \\
\text { (Kassas 1957, Alawad 1994, Sugga 1999, Karrar 2010, Vetaas et al. 2012). }\end{array}$ \\
\hline$* 10$ & $\begin{array}{l}\text { Caroxylon spinescens (Moq.) Akhani \& Roalson (= Salsola spinescens Moq.). Red Sea Coasts } \\
\text { (Alawad 1994, Woldewahid et al. 2007). }\end{array}$ \\
\hline 11 & $\begin{array}{l}\text { Caroxylon vermiculatum (L.) Akhani \& Roalson (= Salsola vermiculata L.). Northern Sudan } \\
\text { (Andrews 1950), Wadi Halfa (Broun \& Massey 1929, Pettet et al. 1964, Ahti et al. 1973), Red } \\
\text { Sea Coasts (Kassas 1957, Hassan 1974, Alawad 1994). }\end{array}$ \\
\hline$* 12$ & $\begin{array}{l}\text { Caroxylon villosum (Schult.) Akhani \& Roalson (=Salsola villosa Schult.). Red Sea Coasts } \\
\text { (Alawad 1994). }\end{array}$ \\
\hline 13 & $\begin{array}{l}\text { Chenopodiastrum murale (L.) S.Fuente, Uotila \& Borsch. (= Chenopodium murale L.). } \\
\text { Northern and Central Sudan (Broun \& Massey 1929, Andrews 1950, Ali 2004, Tathir 2013, Ishag } \\
\text { et al. 2016, Hamad et al. 2020), Red Sea Coasts (Woldewahid et al. 2007, Alawad 1994), Kassala } \\
\text { (Ahti et al. 1973), Jebel Marra (Good 1924, Wickens 1976). }\end{array}$ \\
\hline$* 14$ & $\begin{array}{l}\text { Chenopodium album L. Central Sudan (Broun \& Massey 1929, Braun et al. 1991, Hamad et al. } \\
\text { 2020). }\end{array}$ \\
\hline 15 & Chenopodium opulifolium Schrad. ex Koch \& Ziz. Jebel Marra (Wickens 1976). \\
\hline 16 & $\begin{array}{l}\text { Cornulaca ehrenbergii Aschers. Red Sea Coasts (Broun \& Massey 1929, Andrews 1950, Hassan } \\
\text { 1974, Alawad 1994). }\end{array}$ \\
\hline 17 & $\begin{array}{l}\text { Cornulaca monacantha Del. Northern Sudan (Broun \& Massey 1929, Andrews 1950, Kehl } \\
\text { 1987), Red Sea Coasts (Hassan 1974, Alawad 1994). }\end{array}$ \\
\hline$* 18$ & $\begin{array}{l}\text { Dysphania procera (Hochst. ex Moq.) Mosyakin \& Clemants. (= Chenopodium procerum } \\
\text { Hochst. ex Moq.,). Sudan (Brenan 1954). }\end{array}$ \\
\hline 19 & $\begin{array}{l}\text { Dysphania schraderiana (Schult.) Mosyakin \& Clemants (= Chenopodium schraderianum } \\
\text { Schult.). Western Sudan (Broun \& Massey 1929, Andrews 1950, Wickens 1976). }\end{array}$ \\
\hline 20 & $\begin{array}{l}\text { Halocnemum strobilaceum (Pall.) M. Bieb. (=Halopeplis perfoliata (Forssk.) Bunge ex Ung.- } \\
\text { Sternb. Red Sea Coasts (Broun \& Massey 1929, Andrews 1950, Kassas 1957, Hassan 1974, } \\
\text { Alawad 1994, Sugga 1999, Woldewahid et al. 2007, Karrar 2010), Kassala (Ahti et at.1973). }\end{array}$ \\
\hline$* 21$ & Haloxylon salicornicum (Moq.) Bunge ex Boiss. North- western Sudan (Madani et al. 2015). \\
\hline 22 & $\begin{array}{l}\text { Kochia cana Bunge ex Boiss. Red Sea Coasts (Broun \& Massey 1929, Andrews 1950, Kassas } \\
\text { 1957). The presence of this species in Sudan is doubtful. Boissier }(1879,4: 924) \text { defines this } \\
\text { species as an annual species, while according to Andrews }(1950,1: 111) \text { and Broun \& Massey } \\
(1929: 79) \text {, it is described as branched undershrub. Moreover, the distribution area of this Irano- }\end{array}$ \\
\hline
\end{tabular}




\begin{tabular}{|c|l|}
\hline 23 & Turanian species doesn't reach even the Arabian peninsula. \\
\hline 24 & $\begin{array}{l}\text { Salicornia fruticosa (L.) L (= Sarcocornia fruticosa (L.) A.J. Scott.). } \\
\text { Red Sea Coasts (Andrews 1950, Hassan 1974, Alawad 1994, Karrar 2010). }\end{array}$ \\
\hline $\begin{array}{l}\text { Sevada schimperi Moq. (= Suaeda schimperi (Moq.) Ulbr., S. vermiculata Forssk., var. puberula } \\
\text { 1991). }\end{array}$ \\
\hline 26 & $\begin{array}{l}\text { Suaeda aegyptiaca (Hasselq.) Zohary (=Schanginia hortensis (Forssk.) Moq., Suaeda hortensis } \\
\text { Forssk. ex J.F. Gmel.). Red Sea Coasts (El Amin 1990, Alawad 1994). }\end{array}$ \\
\hline $\begin{array}{l}\text { Suaeda fruticosa Forssk. ex J.F. Gmel (=Suaeda volkensii C.B. Clarke). } \\
\text { Red Sea Coasts (Broun \& Massey 1929, Andrews 1950, Kassas 1957, Hassan 1974, El Amin } \\
\text { 1990, Alawad 1994, Sugga 1999, Woldewahid et al. 2007 Karrar 2010), Kassala (Alhti et al. }\end{array}$ \\
\hline $\begin{array}{l}\text { 1973). } \\
\text { Suaeda monoica Forssk. ex J.F. Gmel. Northern Sudan (Broun \& Massey 1929, Andrews 1950), } \\
\text { Red Sea Coasts (Kassas 1957, Hassan 1974, El Amin 1990, Alawad 1994, Sugga 1999, } \\
\text { Woldewahid } \text { et al. 2007, Karrar 2010, Nuri } \text { et al. 2016), Kassala (Ahti } \text { et al. 1973). }\end{array}$ \\
\hline 28 & $\begin{array}{l}\text { Suaeda vermiculata } \text { Forssk. ex J.F. Gmel. Red Sea Coasts (Andrews 1950, Kassas 1957, Hassan } \\
\text { 1974, Sugga 1999, Karrar 2010), Suakin (Broun \& Massey 1929). }\end{array}$ \\
\hline
\end{tabular}

\section{Discussion and conclusion}

A total number of (28) species were compiled to comprise members of the family Chenopodiaceae in Sudan, with the addition of (12) species belonging to (8) genera, regarded as new records not previously documented in the main flora of Sudan (Andrews 1950). These (12) newly recorded species were identified as a result of an extensive literature review on various floristic studies published from different regions of Sudan, herbarium collections deposited at (KHU), and long-term field surveys.

(20) species out of the $(28)$ species $(\approx 70 \%)$ of the species compiled are reported from the Red Sea Coastal salt Marshes. This area is situated at the northeastern corner of Sudan and is extensively studied unlike other regions of the country. The floristic composition of the Red Sea Coastal region was studied by Kassas (1957), Berry (1964), Hassan (1974), El Shourbagy et al. (1987), Alawad (1994), Sugga (1999), Hegazy et al. (2007), Woldewahid et al. (2007), Karrar (2010), Vetaas et al. (2012), in addition to annual expeditions to the area by undergraduate students of various Universities.

In addition to the species newly recorded in recent studies at the Red Sea Coasts (e.g. Bassia eriophora, Chenopodiastrum murale), some other species (e.g. Anabasis ehrenbergii, Kochia cana, Sevada schimperi), although were previously recorded by Andrews (1950), Kassas (1957) and Hassan (1974) in the same area, were not documented by subsequent floristic studies and may be regarded as extinct or vanished. Such changes in the floristic composition were attributed to browsing, climatic changes (Vetaas et al. 2012), and destruction of natural habitats due to salt pans construction and pollution from Port-Sudan and Suakin harbours (Karrar 2010).

The present study also reported geographical range extension of (6) species to new locations found beyond their known range previously cited in the Flora by Andrews (1950). These species include: Atriplex farinosa, Chenopodiastrum murale, Cornulaca monacantha, Halocnemum strobilaceum, Caroxylon imbricatum and Caroxylon vermiculatum. While some plants are adapted to a wide range of environmental conditions and have range extension, many others are quite habitat-specific (e.g. Anabasis setifera, Anabasis ehrenbergii, Bassia eriophora, Cornulaca ehrenbergii, Caroxylon spinescens, Caroxylon villosum, Salicornia fruticosa, Suaeda aegyptiaca, Sevada schimperi and Suaeda vermiculata.

The taxonomic status of the botanical name Kochia cana is still doubtful and not standardized. According to The Plant List (http://www.theplantlist.org) the status of Kochia cana is unresolved. The Royal Horticultural Society (https://www.rhs.org.uk) regarded Kochia cana a tentatively accepted name, the African Plant Database (http://www.ville-ge.ch) consider it as accepted name, whereas according to (https://sv.wikipedia.org) it is regarded as a synonym to Bassia stellaris (Moq.) Bornm. Scott (1978) reported that the presence of winged or spinescent accrescent perianth, which distinguish the genera Kochia and Bassia, is not sufficient justification for maintaining them as separate genera and were amalgamated in the genus Bassia. Kochia cana is an intermediate species with the accrescent perianth in the form of scales or horizontal crests. Moreover, Turki et al. (2008) rejected the amalgamation and supported their treatment as different genera.

\section{Acknowledgements:}

I am grateful to professor Helmut Freitag, Universitat Kassel, Germany, and professor Alexander P. Sukhorukov, Lomonosov Moscow State University, Russia, for their valuable comments and suggestions on the previous preprint version of the manuscript. 


\section{References:}

1. Ahti, T.T., Hamet-Ahti, L. and Pettersson, B. (1973). Flora of the inundated Wadi Halfa reach of the Nile, Sudanese Nubia, with notes on adjacent areas. Annales Botanici Fennici, 10(2): 131-162. https://www.jstor.org

2. Akhani, H., Edwards, G. and Roalson, E.H. (2007) Diversification of the Old World Salsoleae s.l. (Chenopodiaceae): Molecular phylogenetic analysis of nuclear and chloroplast data sets and a revised classification. International Journal of Plant Sciences, 168(6): 931-956. https://doi.org/10.1086/518263.

3. Alawad, A.A. (1994). Eco-taxonomical studies in the Red Sea Hills Flora. PhD Thesis, Graduate College, University of Khartoum, Sudan.

4. Ali, M.M. (2004). Aquatic and shoreline vegetation of Lake Nubia, Sudan. Acta Botanica Croatica, 63(2): 101-111. https://www.sementicscholar.org.

5. Ali, M.M. (2006). Shoreline vegetation of Lake Nubia, Sudan. Hydrobiologia, 570: 101-105. https://doi.org/10.1007/s10750-006-0168-2.

6. Andrews, F.W. (1950). The flowering plants of the AngloEgyptian Sudan, volume I. Buncle \& Co., Ltd., Arbroath, Scotland. http://digital-uib.no/1956.2/2479.

7. APG (Angiosperm Phylogeny Group I) (1998). An ordinal classification for the families of flowering plants. Annals of the Missouri Botanical Gardens, 85: 531-553. https://doi.org/10.2307/2992015.

8. APG (Angiosperm Phylogeny Group II) (2003). An update of the Angiosperm Phylogeny Group Classification for the orders and families of flowering plants. Botanical Journal of the Linnaean Society, $141 \quad$ (4): 399-436. https://doi.org/10.1046/j.1095-8339.2003.t01-1-00158.x.

9. APG (Angiosperm Phylogeny Group III) (2009). An update of the Angiosperm Phylogeny Group Classification for the orders and families of flowering plants. Botanical Journal of

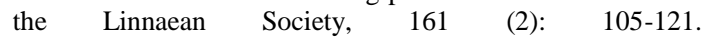
https://doi.org/10.1111/j.1095-8339.2009.00996.x

10. APG (Angiosperm Phylogeny Group IV) (2016). An update of the Angiosperm phylogeny Group classification for the orders and families of flowering plants. Botanical Journal of the Linnaean Society, 181(1): 1-20. https://doi.org/10.1111/boj12385.

11. Bentham, G. and Hooker, J.D. (1880). Genera Plantarum. Reeve \& Co., London. https://doi.org/10.5962/bhl.title.747.

12. Berry, L. (1964). The Red Sea Coast of the Sudan. Sudan Notes and Records, 45:148-157. https://www.jstor.org/stable/41716864.

13. Boissier, E. (1879). Flora orientalis: sive, enumeratio plantarum in Oriente a Graecia et Aegypto ad Indiae fines hucusque observatarum, vol. 4. Corolliflorae et Monochlamydeae. H. Georg Basle and Geneva, Switzerland. https://doi.org/10.5962/bhl.title.20323.

14. Boulos, L. (1999). Flora of Egypt, volume one (AzollaceaeOxalidaceae). Al Hadara Publishing, Cairo, Egypt

15. Boulos, L., Friis, I. and Gilbert, M.G. (1991). Notes on the Chenopodiaceae of Ethiopia, Somalia and Southern Arabia. Nordic Journal of Botany, 11(3): 309-316. https://doi.org/10.1111/j.1756-1051.1991.tb01409.x.

16. Braun, M., Burgstaller, H., Hamdoun, A.M. and Walter, H. (1991). Common weeds of Central Sudan. GTZ, Eschborn, Germany. https://www.si.edu.

17. Brenan, J.P.M. (1954). Chenopodiaceae. In: Turrill, W.B., Milne-Redhead, E. (eds.), Flora of Tropical East Africa.. Crown Agents for Overseas Governments and Administrations. https://press.uchicago.edu.

18. Broun, A.F. and Massey, R.E. (1929). Flora of the Sudan. Thomas Murby and Co., London.

19. Brummitt, R.K. (2001). World geographical scheme for recording plant distributions. International Working Group on Taxonomic Data Basis for plant sciences (TDWG). https://en.wikipedia.org
20. Cronquist, A. (1981). An integrated system of classification of flowering plants. Columbia University Press, New York.

21. El Amin, H.M. (1990). Trees and shrubs of the Sudan. Ithaca Press, Exeter. https://cabdirect.org.

22. El Hadidi, M.N. (1976). The riverian flora in Nubia. In: J. Rzoska (ed.), The Nile, biology of an ancient river. Monographiae Biologicae, 29:87-91. https://doi.org/ 10.1007/978-94-010-1563-9 11.

23. El Shourbagy, M.N., Al- Eidaros, O.H. and Al Zahrani, H.S. (1987). Distribution of Halopeplis perfoliata (Forssk.) Bunge ex Schweinf. in the Red Sea Coastal salt marshes: phytosociological relations and responses to soil. Journal of Coastal Research, 3(2): 179-187. https://journals.flvc.org

24. FAO (2005). Sudan. In: Aquastat survey. FAO Land and Water Development Division, FAO. http://www.fao.org

25. Freitag, H., Hedge, I.C., Jafri, S.M.H., Kothe-Heinrich, Omer, S. and Uotla, O. (2001). Chenopodiaceae. In: S.I. Ali \& M. Qaiser (eds.), Flora of Pakistan, 204:178-183. Missouri Botanical Gardens Press. www.efloras.org.

26. Fuentes-Bazen, S., Uotila, P. and Borsch, T. (2012). A novel phylogeny-based generic classification of Chenopodium sensu lato, and a tribal rearrangement of Chenopodioideae (Chenopodiaceae). Willdenowia, 42(1): 5-12. https://doi.org/10.3372/wi.42.42101.

27. Good, R. (1924). The geographical affinities of the flora of Jebel Marra. New Phytologist, 23(5): 266-282. https://onlinelibrary.wiley.com

28. Hamad, M.S., Ali, F.S.M., Mohammed, S.A.A. and Kordofani, M.A. (2020). Checklist of the flora of Tutt Island, Khartoum Province, Sudan. Journal of Agriculture and Ecology Research International, 21(4): 27-40. https://doi.org/10.9734/JAERI/2020/v21i430139.

29. Hassan, H.M. (1974). An illustrated guide to the plants of Erkowit. Khartoum University Press, Khartoum, Sudan.

30. Hegazy, A.K., Lovett- Doust, J., Hammouda, O. and Gomaa, N. (2007). Vegetation distribution along the altitudinal gradient in the northwestern Red Sea Region. Community Ecology, $8(2)$ : https://doi.org/10.1556/ComEc.8.2007.2.2.

31. Hernandez-Ledesma, P., Berendsoh, W.G., Borsch, T., Von Mering, S., Akhani, H., Arias, S., Castaneda-Noa, I. et al. (2015). A taxonomic backbone for the global synthesis of species diversity in the Angiosperm order Caryophyllales. Willdenowia, $45(3)$ : http://dx.doi.org/10.3372/wi.45.45301.

32. Ishag, M., Abdelkreem, M.I.M. and Ibrahim, D.A. (2016). Checklist of flora and vegetation of an archeological habitat in North Sudan. Pyrex Journal of Biodiversity and Conservation, 1(1): 1-9. http://www.pyrexjournals.org/pjbc.

33. Kadereit, G., Borsch, T., Weising, K. and Freitag, H. (2003) Phylogeny of Amaranthaceae and Chenopodiaceae and the evolution of C4 photosynthesis. International Journal of Plant Sciences, 164: 959-986. https://doi.org/10.1086/378649.

34. Karrar, O.O. (2010). Overview of halophytic plants of the Sudanese Red Sea salt marsh. In: Ozturk, M., Boer, B., Barth, H.J., Clusener- Godt, M., Khan, M. and Breckle, S.W. (eds.), Sabkha ecosystem. Sabkha Ecosystems, 3:45-51. https://doi.org/10.1007/978-90-481-9673-9_6.

35. Kassas, M. (1957). On the ecology of the Red Sea coastal land. Journal of Ecology, 45 (1): 187-203.

36. Kehl, H. (1987). Zonation and establishment of vegetation in selected uninhabited Egyptian and Sudanese Oases. CATENA, 14(4): 275-299. https://doi.org/10.1016/03418162(87)90021-X.

37. Madani, I., Tahir, Y.F., Hamdeen, H.M., Pokorna, A. and Pokorny, P. (2015). Vegetation ecology and taxonomy of El Ga'ab area, Northwestern Sudan. European Academic Research, 3(3): 2927-2943. https://www.researchgate.net/publication/276390547.

38. Mosyakin, S.L. and Clemants, S.E. (2008). Further transfers of glandular-pubescent species from Chenopodium subg. Ambrosia to Dysphania (Chenopodiaceae). Journal of the 
Botanical Research Institute of Texas, 2(1): 425-431. https://www.researchgate.net/publication/271500164.

39. Nuri, A.A.F. Hamid, A.A. Ali, E.D.M. and Salih, E.M (2016). Assessment of vegetation cover degradation using remote sensing and GIS techniques along Sudanese Red Sea Coast (Suakin to Ashad). Journal of Geography and Geology, 8(1): 55-64. https://doi.org/10.5539/jgg.v8n1p55.

40. Pettet, A., Pettet, S.J., Cloudsley-Thompson, J.L. and Idris, B.E.M. (1964). Some aspects of the fauna and flora of the district around Wadi Halfa. Natural History Museum Bulletin, 2. https://digitalt.uib.no.

41. Piirainen, M., Liebisch, O. and Kadereit, G. (2017). Phylogeny, biogeography, systematics and taxonomy of Salicornioideae (Amaranthaceae/ Chenopodiaceae): A cosmopolitan, highly specialized hygrohalohalophyte lineage dating back to the Oligocene. Taxon, 66(1): 109-132. https://doi.org/10.12705/661.6.

42. Scott, A.J. (1978). A revision of the Camphorosmioideae (Chenopodiaceae). Feddes Repertorium, 89(2-3): 101-119. https://doi.org/10.1002/fedr.19780890202.

43. Sugga, A.A.B. (1999). On the ecology of Sudanese Red Sea coastal vegetation with emphasis on mangrove ecosystem. $\mathrm{PhD}$ Thesis, Graduate College, University of Khartoum. http://hdl.handle.net/1834/6793.

44. Tathir, Y.F. (2013). Flora and fauna of the Third Cataract Region, Sudan. Sudan Biota, 1: 14-23. https://www.academia.edu
45. Thorne, R.F. (1992). An updated phylogenetic classification of the flowering plants. Aliso: A Journal of Systematic and Evolutionary $\quad$ Botany, 13(2): 365-389. https://doi.org/10.5642/aliso.19921302.08.

46. Turki, Z., El Shayeb, F. and Shehata, F. (2008). Taxonomic studies in the Camphorosmeae (Chenopodiaceae), 1. Subtribe Kochiinae (Genera: Bassia All., Kochia Roth. and. Chenolea Thunb.). Acta Botanica Hungarica, 50(1-2): 181-201. https://pubag.nal.usda.gov.

47. Vetaas, O.R., Salih, E.A. and Jurasinski, G. (2012). Vegetation changes in the Red Sea Hills: from mist oasis to arid shrub. Plant Ecology and Diversity, 5(4): 527-539. https://doi.org/10.1080/17550874.2012.749954.

48. Ulbrich, E. (1934). Chenopodiaceae. In: Engler, A. \& Prantl, K. (eds.). Die naturlichen Planzenfamilien, vol. $16 \mathrm{c}$. Engelmann, Leipzig. https://doi.org/105962/bhl.title.4635.

49. Wickens, G.E. (1976). Flora of Jebel Marra (Sudan Republic) and its geographical affinities, University of Chicago Press, Chicago. https://press.uchicago.edu.

50. Woldewahid, G., van der Werf, W., Sykora, K.V., Abate, T., Mostofa, B. and van Huis, A. (2007). Description of plan communities on the Red Sea coastal plain of Sudan. Journal of Arid Environments, 68(1): 113-131.

51. https://doi.org/10.1016/j.jaridenv.2006.04.003.

52. Zhu, G., Mosyakin, S.L. and Clemants, S.E. (2003). Chenopodiaceae. In: W. Zhengyi \& P.H. Raven (eds.), Flora of China, 5: 351-414. https://www.efloras.org. 